\title{
Trembesi Digestibility Fermented By Lactobacillus Plantarum Mut 7
}

\author{
${ }^{1}$ Ahimsa Kandi Sariri, and ${ }^{1}$ Sri Sukaryani \\ Animal Husbandry, Agriculture Faculty, Universitas Veteran Bangun Nusantara \\ J1. Letjen Sujono Humardani No. 1, Sukoharjo 57521, Central Java, Indonesia \\ Email : ak_sariri@ymail.com
}

\begin{abstract}
Abstraact
The specific purpose of this third year research is to study the level of digestibility in vivo BTTF and BTF and to study the effect of the use of tamarind leaves by the method of increasing the quality of nutrient content and decreasing saponin in PO cattle feed (ongole breeds). The specific target of the third year is BTTF and BTF in vivo digestibility. This study was designed with a Completely Randomized Directional Design with two treatments, namely in vivo digestibility BTTF and BTF. From this study it can be concluded that the level of digestibility in vivo from BTF was $53.33 \%$ and was significantly different from BTTF.
\end{abstract}

Keywords: in vivo digestibility, trembesi

\section{Introduction}

Previously, the results showed that by using microbes Aspergillus niger and Lactobacillus plantarum can reduce the saponin content in leaves, young fruits, and the skin of young trembesi fruit (Sammanea saman). Between Aspergillus niger and Lactobacillus plantarum there were no significant difference in reducing the saponin content, but Lactobacillus plantarum significantly increased the crude protein content in the seeds and skin of young trembesi fruit compared with Aspergillus niger.

In subsequent research, an optimization of using Lactobacillus plantarum to get the best results from the microbes used. With the optimization, it turns out that it can reduce saponins to a tolerable level $(0.22 \%)$. The study also analyzed the level of in vitro digestibility of fermented trembesi, and obtained the results of fermented tamarind digestibility of $41.14 \%$.

Based on the results of research that has been carried out, an in vivo digestiblity test needed to be done. With in vivo digestibility test, we expected to learn how cattles would respond to the given feed ingredients. So it is recommended that the use of fermented trembesi by using Lactobacillus plantarum in ruminant animal feed rations.

This study aims to study the in vivo digestibility level of BTTF (unfermented trembesi material) and BTF (fermented trembesi material) and study the effect of utilization of trembesi leaves by the method of increasing the quality of nutrient content and decreasing saponin in PO feeds (ongole breeds).

\section{Materials and Methods}

This research was carried out at the Laboratory of Chemistry and Microbiology at Veterans University Bangun Nusantara. Saponin analysis was carried out in two places, for the whole preparation was carried out at the Bangun Nusantara Veterans University, while the saponin content was carried out in the Biology Laboratory of the Faculty of 
Pharmacy UGM. In vivo Digestion Test was carried out in the stable group of the Livestock Bhakti Manunggal, Delingan Subdistrict / Karanganyar Regency.

There are two groups of substrate, namely the part of the trembesi plant (leaves, young fruit and fruit skin) that does not get the fermentation treatment (BTTF) and the group part of the trembesi plant (leaves, young fruit and fruit skin) which gets the fermentation treatment (BTF) using Lactobacillus plantarum.

To test the level of digestibility in vivo, in this research Ongole Breed Cattles (PO) were used as subjecfts. There are three PO cows used for each treatment. PO cattle are fed according to treatment for 14 days and the collected faeces are used for analysis. To avoid decomposition until laboratory analysis is performed, the stool is stored in a freezer.

This study was designed with a Completely Randomized Design in a unidirectional pattern with two treatments, namely BTTF and BTF digestibility, each treatment was applied to six PO cows.

In vivo experiments were conducted in three periods, namely: adjustment period, preliminary period, and collection period (Soejono, 2004).

Data were analyzed using Analysis of Variance (ANOVA) unidirectional pattern. Further tests using Duncan's Multiple Range Test (DMRT) (Christensen, 1996).

\section{Results and Discussion}

This study aims to study the response of Ongole (PO) breeds to fermented trembesi through in vivo digestibility testing. To obtain differences in the response of PO cows to their digestibility, two treatments were carried out, namely feeding fed unfermented trembesi (BTTF) and feeding fed fed fermented trembesi (BTF). PO cattle are treated with two stages of feed. The first stage is the preliminary phase lasted for 7 days and the collection period for 7 days. In vivo digestibility levels of BTF and BTTF can be seen in Table 1.

Table 1. In vivo trembesi digestibility level

\begin{tabular}{ccc}
\hline Treatment & In vivo digestilibity $(\%)$ \\
\hline & BTTF & $35,12^{\mathrm{a}}$ \\
BTF & $53,33^{\mathrm{b}}$ \\
\hline
\end{tabular}

${ }^{\mathrm{ab}}$ superscript shows the real difference $(\mathrm{P}<0,5)$

Table 1 shows that in vivo BTF digestibility was significantly different compared to BTTF. Digestion is an important indication to know, because digestion can be used as a clue about the use of feed by livestock, to determine the amount of nutrients from the feed material absorbed by the digestive tract or part of the feed that is not excreted in faeces (Mc. Donald, 1988).

According to Leng (1980) that the highest digestibility occurs due to the high PK content and the large amount of microbial protein that can escape rumen degradation, so that it is digested in the post rumen with the help of the enzyme pepsin enzyme. Fermented products that are not absorbed through the rumen wall will be digested in the post rumen which functions the same as the stomach and small intestine, namely carrying out enzymatic digestion and absorption of nutrients needed by cattles. 
Rachman (1989), Judoamidjojo et al. (1992) and Tisnadjaja (1996) state that fermentation is the use of microbes to increase the added value of a substance or substrate. And with fermentation, it removoes anti-nutrient substances that are toxic (Suliantari and Rahayu, 1990). This is indicated in the results of the second year of research that produced saponin content below the threshold value of $0.22 \%$. With the decrease in saponin content in the trembesi, the quality of the trembesi is increasing, with the increase in feed quality being positively correlated to the palatability of the feed. Palatability of ruminant animal feed is strongly influenced by its protein content. The crude protein content of fermented trembesi is $9.56 \%$ (Sariri et al., 2012), with the high protein content, it will increase the palatability of feed as indicated by the increase in feed consumption. The higher the feed consumption the higher the value of digestibility.

Conclusion

\section{Conclusion}

From this study it can be concluded that the level of digestibility in vivo from BTF was $53.33 \%$ and significantly different from BTTF.

Suggestion

From the results of the first, second and third year of research it can finally be suggested that new innovations can be made in the packaging and dissemination of research results in the form of low fermented saponin trembesi flour which can be used as a substitute for protein feed as well as a source of fiber for ruminants.

\section{References}

Christensen, R. 1996. Analysis of variance, Design and Regression : Applied Statistical Methods. Chapman and Hall. London

Judoamidjojo, M., A.a. Darwis dan E.G. said. 1992. Teknologi Fermentasi. Rajawali Press. Jakarta.

Leng, R.A. 1980. Principlis and Practices Of Feeding Tropical and By Product to ruminant. University of New England. Armidale.

McDonald, P., R.A. Edwards, and J.F.D. Greenhalgh. 1988. Animal Nutrition. 4 edition. Longman Scientific \& Technical. England.

Prawirokusumo, Soeharto. 1993. Ilmu Gizi Komparative. BPFE. Yogyakarta.

Rachman, A. 1989. Pengantar Teknologi Fermentasi. PAU-IPB. Bogor

Suliantari dan W.P. Rahayu. 1990. Teknologi Fermentasi Biji-bijian dan Umbi-umbian. PAU-IPB. Bogor.

Soejono, Mohammad. 2004. Petunjuk Laboratorium Analisis dan Evaluasi Pakan. Laboratorium Teknologi Makanan Ternak Jurusan NMT fakultas Peternakan UGM. Yogyakarta..

Tillman, Allen D., Hari H, Soedomo R, Soeharto P, P. Soekanto L. 1984. Ilmu Makanan Ternak Dasar. UGM Press. Yogyakarta. 